\title{
Default Risk of the UK Real Estate Companies: Is There a Macro-economy Effect?
}

\author{
Prodromos Vlamis ${ }^{1}$ \\ University of Cambridge
}

\begin{abstract}
The aim of this paper is to empirically identify the factors which are important in explaining default risk of the UK real estate companies over the past 20 years. We estimate a pooled probit econometric model where the probability of failure is expressed as a function of both macroeconomic variables (inflation, interest rates etc) and company financial ratios. The inclusion of macroeconomic variables marks a departure from most previous studies of company bankruptcy. We find that the most important determinants of bankruptcy of the UK real estate companies are company liquidity, profitability and debt coverage as well as financial market volatility, interest rates, current account and the economic cycle. The latter provides evidence that the macro-economy crucially affects the probability of default of the real estate industry in the UK.
\end{abstract}

JEL Classification: C35, G33, L85.

Keywords: Default probability, Probit binary-response Model, Real estate companies.

\section{Introduction}

The worldwide recession in the early 1990s brought significant pressure to the UK economy. Things went worse due to the entrance of the British pound into the Exchange Rate Mechanism (ERM) of the European Monetary System (EMS) on $8^{\text {th }}$ October 1990. The British pound entered ERM in a higher exchange rate than what the foreign exchange currency markets thought was, at the time, its equilibrium exchange rate. The British conservative government followed a contractionary monetary policy especially during 1992, to combat inflationary pressures and to defend the exchange rate (within the ERM narrow band) from the speculative attacks emerged in early 90 's. This naturally led to an increase in interest rates ${ }^{2}$. The increased interest rates in close relation to the fact that most of the UK companies' debt is at floating interest rates ${ }^{3}$ made a number of real estate companies unable to service their debts. The simultaneous fall in i) property rents by over 20\% (Davis, 1995) due to an increase in supply of retail and office stock in the early 90 's and ii) in commercial property prices by over $25 \%$ (Davis, 1995) due to the general economic recession, led many property companies to insolvency. Given that around $10 \%$ of the total bank loans, at the time, were diverted to property companies (Ball et al, 1998), real estate defaults had a negative feedback effect to the whole economy; credit risk was transferred from the real estate companies to the whole economy through the banking system (Logan, 2000). Thus, the recession was deepened and unemployment rate increased. This led to wide spread concern among the British government, the Bank of England, banks and the real estate industry professionals. It was made obvious to the policy makers, commercial banks and investors that real estate company failures, banking crises and macroeconomic recessions were intertwined ${ }^{4}$.

The need to introduce a failure prediction model for real estate companies in order to explain the factors that affect their probability of default has never been greater. The purpose of this paper is to build up an econometric model able to identify the factors that have a significant impact on the probability of default of the UK real estate companies. Kane et al (1996) suggest that financial distress resulting in corporate failure can be dichotomised into two groups: 1) Macro-economic stress induced by a firm's exposure to events such as a general recession, and 2) Micro-economic stress resulting from firm and industry specific causes. Along these lines we estimate a pooled probit model where the probability of failure is expressed as a function of both macroeconomic variables (inflation, interest rates etc) and company financial ratios. The analysis is based on a unique panel data set collected from Thompson's DataStream (total number of 139 companies) for the period 1980 to 2001. We find that the most important determinants of bankruptcy of the UK real estate companies are company liquidity, profitability and debt coverage as well as financial market volatility, interest rates, current account and the economic cycle. The 
latter provides evidence that the macro-economy crucially affects the probability of default of the real estate industry in the UK.

There are three basic reasons that lead us to believe that the results presented in this paper contribute to the existing literature on default risk. First, quantitative credit risk analysis of the real estate industry in the UK has not yet been developed. Patel and Vlamis (2006) were the first to look at this issue. Based on the Black, Scholes (1973) and Merton (1974) contingent claims model, they estimate the distance-to-default and the "risk neutral" default probabilities for a sample of 112 real estate companies over the period 1980 to 2001 . They use a conceptual model ${ }^{5}$ to predict the probability of default of the UK real estate companies. We extend this work by using an econometric model ${ }^{6}$ instead, that is a Probit model, in order to identify the determinants of the probability of default of the UK real estate companies. Altman (1998) points out that developments and tests of Probit and Logit models have dominated the credit risk measurement literature in the scholarly journals. Nevertheless, we have not as yet seen an attempt of this kind in the literature for the UK real estate companies. One explanation for this lack of empirical work on the area is that very often real estate companies -together with companies in finance and insurance industry- are excluded from corporate financial distress studies because their financial accounts are not comparable to the rest of the companies. Second, the data set of the UK real estate companies employed represents one of the most extensive and detailed data sets in the study of real estate companies default. Third, one of the distinctive features of this study is to test the extent to which macroeconomic circumstances also contribute to real estate company failure. To the best of our knowledge none of the studies in this area provides systematic treatment of the state of the macro-economy as a contributory factor explaining real estate corporate failure. We think that this issue is an important empirical one, especially in the case of industries like construction and commercial real estate, which are prone to cyclical activity.

The rest of the paper is organized as follows. In section 2 a brief review of the literature is provided. In section 3 the Probit econometric model is outlined. Section 4 provides a description of the data collected. In Section 5 we present the explanatory variables used in our model. In Section 6 we discuss the Probit results and Section 7 concludes the paper.

\section{Review of the Literature}

Multivariate methods utilize two or more key accounting variables to explain failed and non-failed companies. The independent variables are combined and weighted in order to produce either a credit risk score or a measure of the probability of default. The three approaches to developing multivariate creditscoring systems are the Linear Probability Model ${ }^{7}$, the Zeta Discriminant Model and the Probit/Logit model. Altman (1968) is the first to apply statistical techniques, particularly the use of Discriminant Analysis, to identify bankruptcy risk of non-financial firms. This method divides borrowers into high or low default risk classes contingent on their observed characteristics. He maintains that there are several financial ratios that are of key importance to company failure. These ratios could act as an indicator of the company's propensity to fail. Later, Altman et al. (1977) produced a revised version of Altman's original equation, which is referred to as the ZETA Discriminant Model. This is based on the same philosophy but extends the number of independent variables employed (7-variable model). They apply their model in a sample of 53 bankrupt non-financial companies and a matched sample of 58 non-bankrupt entities in the USA, for the period 1969-1975. They follow an iterative process to end up with a model that gives the significant determinants of the probability of default; return on assets, stability of earnings, debt service, cumulative profitability, liquidity, capitalization and company size. Martin (1977) is the first to apply Logit/Probit model to measure the soundness of the US commercial banking system. Martin's data set comprises the entire population of banks being members of the Federal Reserve System; approximately 5,700 with 58 of them having failed between 1970 and 1976. After running a number of regressions, he concludes that the Logit model, with 4 independent variables characterizing profitability (net income/total assets), asset quality (commercial loans/total loans), capital adequacy (gross capital to risky assets) and expenses/operating revenues, is the most satisfactory model. It also turns out that Logit model is superior to Discriminant Analysis when the criterion is solely the probability of default estimation. Heffernan (1995 and 1996) employs an international database with 27 healthy and 12 failed banks to identify the causes of bank failure. He estimates conditional Logit model for the period between 1989 and 1992. His sample includes the following countries: Australia, Finland, France, Norway, Sweden and the United States. He finds that net income/total assets (profitability), equity/total assets (capital adequacy), the growth rate of $G D P$, the nominal and real effective exchange rates, nominal and real interest rates and the rate of 
inflation are variables that significantly explain bank failures. Lennox (1999) evaluates the usefulness of the Probit, Logit and Discriminant Analysis by examining the causes of bankruptcy for a sample of 949 listed companies operating in various industry sectors in the UK; 90 of those companies failed between 1987 and 1994. He finds that the most important determinants of bankruptcy are cash flow, leverage, company size, profitability and the economic cycle. He also claims "that well specified logit and probit models can identify failing companies more accurately than the discriminant analysis". Kolari et al. (2002) estimate a Logit model to identify the factors that caused a surge of bank failures in the United States in the late 1980s and early 1990s. They collect and analyze a sample of 55 large failed banks and around 1,000 large non-failed banks for the period 1989-1992. Kolari et al. find that net interest income/total assets, net income after taxes/total assets, total equity/total assets and net loan charge-offs/total assets have a statistically significant effect on the probability of default of the USA large banks. Foreman (2003), in a recent study of bankruptcy of the US local telecommunications industry, estimates a Logit model using a cross section data set of 77 "Competitive Local Exchange Carriers" (14 bankrupt and 63 non-bankrupts) as of year-end 1999. He finds that the probability of default of the CLECs is crucially affected by traditional financial ratios such as, the earnings per share, the retained earnings to assets, the return on assets and the working capital to sales.

Our model has some similarities with Altman's et al (1977) in both the set up and the results (we will discuss this in section 6). However, the research methodologies employed and the data sizes (we will discuss this in section 4) are different. More specifically, Altman's et al. Zeta Discriminant Analysis and our Probit default prediction model are not directly linked to a theoretical model; there is a lack of a theoretical basis for the selection of the financial ratios. As far as the research methodology employed is concerned, Altman et al. use Discriminant Analysis to divide borrowers/firms into high or low default risk classes contingent on their observed characteristics. This methodology has certain weaknesses (no allowance is made for sampling bias) that led researchers to use Probit and Logit models instead. The logistic and probit formulations are comparable and provide qualitatively similar results. In both Probit and Logit models the estimated range of default probabilities lies between 0 and 1 . The only difference is that for the Logit model the assumed form of the probability function is the cumulative logistic distribution function while for the Probit model the assumed form of the probability function is the cumulative normal distribution function. Since Probit and Logit models have been extensively applied to previous accounting, finance and banking studies ${ }^{8}$ and have been found to perform well, we have chosen to employ the binary response Probit model to analyze the determinants of the probability of default of the UK real estate companies.

\section{Model Specification}

Our econometric model is a discrete regression model in which the dependent variable $Y_{i t}$ is binary, where $i=(1,2,3 \ldots \ldots \ldots \mathrm{N})$ refers to the firms and $t=(1,2,3 \ldots \ldots \ldots \mathrm{T})$ refers to the year. We assume there is an underlying response variable $Y_{i t}^{*}$ defined by the regression relationship

$Y_{i t}^{*}=X_{i t} \beta+\varepsilon_{i t}$

where $X_{i t}$ is the vector of the explanatory variables of the $\mathrm{i}^{\text {th }}$ firm, $\varepsilon$ is the error term (assumed to be standard normal with $\varepsilon_{i} \sim \mathrm{N}\left(0, \sigma^{2}\right)$ and $\beta$ is a vector of coefficients to be estimated. In practice, $Y_{i t}^{*}$ is unobservable. What we observe is the dummy variable $Y_{i t}$ defined by

$Y_{i t}=1 \quad$ if $Y_{i t}^{*} \geq 0$

$Y_{i t}=0 \quad$ otherwise

At each year $t, Y_{i}$ takes the value 1 if a firm has defaulted during the time period $[t-1, t]$ and 0 if the company is "alive". The log-Likelihood Function is given by 
$\ln (L)=\sum_{i}^{\mathrm{N}}\left[\left(1-Y_{i t}\right) \ln \left(1-F\left(X_{i t} \beta\right)\right)+Y_{i t} \ln \left(F\left(X_{i t} \beta\right)\right)\right]$

Because $F(\bullet)$ is strictly between zero and one for probit, $\ln (L)$ is well defined for all values of $\beta$. A non-linear maximum-likelihood estimation procedure is used to obtain parameter estimates for the Probit specification. Econometric theory implies that the maximum-likelihood estimator is consistent, asymptotically normal and asymptotically efficient for random samples.

\section{Data}

Our analysis is based on a pooled unbalanced panel data set, collected from Thompson's DataStream and the financial press ${ }^{9}$, over the period 1980 to 2001. It includes company accounts (Balance Sheets and Profit and Loss Accounts) for the whole population of the de-listed (16 defaulted, 54 taken-over and 19 management buy-outs ${ }^{10}$ ) and the listed (50 non-failed) commercial real estate companies, on the London Stock Exchange, as was their standing on the on $3^{\text {rd }}$ of April 2000. This amounts to over 1,300 observations from company accounts and 139 companies. We acknowledge the fact that our data size is relatively small compared to other empirical work done ((Foreman (2003), Kolari et al (2002), Lennox (1999), Lawrence, Smith and Rhoades (1992), West (1985), Martin (1977) and Altman, Haldeman and Narayanan (1977)). If one limits the study to one country and furthermore focuses on one industry, like we do, the sample inevitably will not be large enough. It has though a number of distinctive features when compared with other empirical work done in the field. We do not follow a "matched pairing" sampling technique, as Altman et al. (1977) and others did, and thus we avoid the weaknesses and problems of this technique. Moreover, if we had followed a "matched pairing technique" we would have ended up with 32 real estate companies (16 failed and 16 non-failed); a sample being too small to identify certain effects on the dependent variable.

From the population of the listed and de-listed UK real estate companies (total of 139 companies) over the period 1980 to 2001, we have only included those with complete data in our model with regards to the selected explanatory variables i.e. financial ratios and macroeconomic time series. Exclusion of companies might lead to a sampling bias. However, as only a very small part of the whole population of companies (only seven companies; Canary Wharf Group, Development Securities, Grainger Trust, Great Portland Estates, Hammerson, Tops Estates and Unite Group) listed to the London Stock Exchange, as of 2000, is excluded due to incomplete data, this bias should not have a significant influence on the estimates of the Probit model parameters. Eichoholtz et al. (2004, p. 7 footnote 2) make a similar argument. A description of all companies (failed and non-failed) employed in this study is given in Appendix I. More specifically, Table 1 in Appendix I, reports the size and the period of analysis for each of the fifty nonfailed companies in the sample. The sub-categories of the sample companies listed on the London Share Service are also presented. Market capitalization is the proxy used for the size of companies and ranges between 1.06 million and 4 billion pounds. The majority of the non-failed companies in our sample (thirtyeight) are listed in the London Share Service under the heading of "Real Estate". There are also eight real estate companies under the heading of "Alternative Investment Market", one under the heading of "Support Services", one under the heading of "Construction" and one under the heading of "Leisure and Hotels". The period of analysis varies among the fifty non-failed companies according to data availability. Financial data covers up to 20 reporting periods (unbalanced panel data set).

There are sixteen companies in the sample that defaulted during the period 1980-2001. For each failed company, financial data from 2 to 10 reporting periods prior to failure has been collected. For the purpose of our econometric model, failed companies are treated as non-failures for all periods up until the period in which they failed. Table 2 in Appendix I, presents the date of delisting of the failed companies (from the London Stock Exchange) and the period of analysis for each of the companies. Thompson's DataStream considers the companies that are de-listed from the London Stock Exchange as "failed". This is not accurate. Companies might get de-listed due to other reasons i.e. because they decide to go private or they are subject to a takeover and management-buy-out bid. A company is deemed to have defaulted, in the legal sense, if it has entered liquidation, receivership or administration. For the purpose of our econometric analysis, we consider a company as failed when it publishes its last company report as an ongoing concern. Failed companies included up to the last report preceding their failure; none of the failing companies have published accounts after filing for bankruptcy. As can be seen from Table 2 in Appendix I, there is a time lag effect between when a company gets under supervision/administration or files for bankruptcy, and 
when it is finally de-listed from the stock exchange. For example Abaco Investments filed its final annual report, prior to entering bankruptcy, in 1986 while the company was delisted nearly two years later, on 02/02/1988. A good look at the companies in Table 2 of Appendix I reveals that this holds for all companies in this category. This is consistent with Peel et al. $(1986$, p. 8) who find that for the UK corporate sector, "the mean time lag from the date of the last account's financial year end to the first notification of failure (comprised the suspension of the firm's listing by the Stock Exchange) is 14 months".

There are forty-nine companies in the sample that were subject to a takeover bid and five companies that merged with other companies, during the period 1980-2001. Table 3 in Appendix I, gives an indication of the size of the merger and takeover activity among the UK real estate companies during this period. The market value of the takeover deals (in British pounds) ranges between 6.33 and 560 million. The market value of the mergers ranges between 13.2 and 160 million. Table 3 also gives details of the actual dates of agreement for the takeover and merger deals. The period of analysis varies among the companies according to data availability. Financial data from 2 to 20 reporting periods, prior to the takeover or merger, was collected. Since these companies were subject to a takeover bid due to their healthy financial condition ${ }^{12}$, we are treating them here as non-failures for all periods including the period in which they were taken-over or merged. There are also thirteen companies in the sample that were subject to a management-buy-out (MBO) bid and six companies that went private during the period 1980-2001. Table 4 in Appendix I, gives an indication of the size of the MBO activity in the UK real estate industry during this period. The market value of the MBO deals (in British pounds) ranges between 4.4 and 500 million. We were able to identify the market value of only two (out of the six) companies that decided to go private. Argent Group and MEPC went private for 18 million and 1.9 billion pounds, respectively. Table 4 also provides the actual dates for the MBO bids recommended. The period of analysis varies among the companies according to data availability. Financial data from 4 to 19 reporting periods, prior to the MBO bid or the decision to go private, was collected. For the purpose of our econometric model, these companies are treated as non-failures for all periods including the period in which the MBO bid was recommended or the company went private

Table 1 shows the frequency of failed and non-failed companies in the pooled panel data set. The frequency of the defaulted companies is $1.20 \%$ (16 observations out of total 1,335$)$ while that of non-failed companies is $98.80 \%(1,319$ observations out of total 1,335). Survivorship bias might arise from the fact that default is a rare event; the observations of the non-failed companies might dominate those of the failed companies. We expect though that as soon as the sample frequency of failure is close to the population frequency, survivorship bias will not be a problem. We believe that the sample frequency of failure in our sample is not much different from the population frequency of failure (given that only seven companies have been excluded from the whole population of the UK real estate companies due to incomplete data). Possibly this is the reason why this kind of sample bias has not attracted any attention in the relevant literature. Survivorship bias is not acknowledged as a problem in recently published work in the area ((see Foreman (2003), Lennox (1999) and Heffernan (1995)).

Table 1. Frequency of Failed and Non-Failed Companies in the Panel Data Set

\begin{tabular}{ccc}
\hline Companies & Frequency & Percent \\
\hline Non-Failed & 1319 & 98.80 \\
Failed & 16 & 1.20 \\
Total & 1335 & 100.00 \\
\hline
\end{tabular}

Table 2 shows the distribution of the observations for the failed and non-failed commercial real estate companies over the period 1980-2001. It is evident that there is a clustering of defaults of real estate companies around the periods that recession hit the UK economy. Particularly, after the stock exchange crash in 1987 until the British pound exited the Exchange Rate Mechanism of the European Monetary System in September 1992, there were eight incidents of defaults. Also, six more companies defaulted during the late 90's economic slump in the UK. The real estate sector in the UK and in many other mature economies experienced a pronounced construction and investment cycle in the late 1980s and early 1990s. Anderson and Sunderesan (2000) point out that default of diverse firms are likely to be correlated to and coincide with cyclical downturn. However, this issue is not specifically addressed in their paper. 
Table 2. Distribution of the observations for the failed and non-Failed Commercial Real Estate Companies

\begin{tabular}{cccccc}
\hline Year & Non-Failed & Failed & Year & Non-Failed & Failed \\
\hline 1980 & 27 & - & 1991 & 63 & 2 \\
1981 & 33 & - & 1992 & 62 & - \\
1982 & 47 & - & 1993 & 60 & - \\
1983 & 56 & - & 1994 & 71 & - \\
1984 & 57 & 1 & 1995 & 74 & - \\
1985 & 60 & - & 1996 & 83 & - \\
1986 & 64 & 1 & 1997 & 89 & - \\
1987 & 61 & 2 & 1998 & 87 & - \\
1988 & 63 & 1 & 1999 & 81 & 2 \\
1989 & 59 & 2 & 2000 & 62 & 4 \\
1990 & 58 & 1 & 2001 & 2 & - \\
\hline
\end{tabular}

\section{Financial Ratios and Macroeconomic Variables as Explaining Factors of Real Estate Company Failure}

As Plat and Plat (1991) correctly put it “...in the case of bankruptcy, there is not a widely accepted theory that might be used to guide model specification". The decision to include an additional variable in a model specification is not based on theoretical considerations that is the choice between different explanatory variables and regression equations is an empirical issue.

We compiled a large number of individual company financial ratios from financial data obtained from companies' annual reports. All data is at fiscal year end. From the total of 22 variables ${ }^{13}$ (11 financial ratios constructed and 11 accounting variables extracted from companies' reports) the most important ones, in terms of statistical significance, were selected. We use a stepwise regression procedure where variables were added to, or dropped from the model, one at a time, based on their statistical significance. We end up including a rather limited number of key financial ratios and accounting variables (four) in order to capture company specific effects. Other studies in accounting, finance and banking literature have included numerous financial ratios to capture the same effects. We believe that beyond a certain point, calculating a greater number of financial ratios adds little additional information. Each new ratio is essentially a variation of other ratios already used in the analysis. Also, we have not selected a number of financial ratios that were found significant in other empirical studies in the corporate failure literature. For example, we do not include "cash" (or other cash related financial ratios) as an explanatory variable in our model because as far as we are aware Thompson's DataStream does not provide Cash Flow Statements for the UK real estate firms. Moreover, we do not provide information about the loan structure (fixed vs. floating) for the UK real estate companies. This distinction is not of prime importance for the UK firms where most of the debt (household and company) is at floating rate. Particularly, the vast majority of loans to firms in the UK (around $90 \%$ of gross loans), are at variable interest rates. Also, a very high proportion of mortgage loans in the UK (around 90\% of the stock of mortgages) have variable interest rates ((Rowlatt (1993), Artis and Lewis (1993), Lewis (1994) and Miles (1994)).

Variables capturing profitability, liquidity, debt coverage and company size are shown in Table 3. Total assets are used as a measure of company size. Company's net income (in millions) taken from the profit and loss accounts is used as a measure of profitability. Earnings before interest and taxes (EBIT) divided by the interest payments is used as a measure of debt service. This measure is of particular interest to lenders who are concerned about a company's ability to repay them for issued loans. Lastly, current assets/total assets ratio is used as a measure of company's liquidity. In addition, from Thompson's DataStream we collected key macroeconomic variables for the UK economy such as inflation, interest rates, current account surplus, growth of GDP and the stock market volatility. The former four variables, which capture business cycle effects and the latter, which captures financial market uncertainty, are summarized in Table 3. The inclusion of macroeconomic variables marks a departure from most previous studies of company bankruptcy. In most studies, authors have restricted themselves to various company financial ratios in their attempts to identify problem or failed companies and their characteristics. One study for banking failure by Heffernan (1995) is an exception of this generalization. Both financial ratios and 
macroeconomic variables included in the study are in percentage terms. The column "Relation to Failure" in Table 3 shows the expected relationship (positive or negative) between the independent variables listed in the table and the state of default.

Table 3. Summary of the Explanatory Variables Used in the Probit Model

\begin{tabular}{|c|c|c|c|}
\hline Variables & Abbreviation & Definition & $\begin{array}{l}\text { Relation to } \\
\text { Failure }\end{array}$ \\
\hline \multicolumn{4}{|l|}{ Financial Ratios } \\
\hline Size of company & Size & $\begin{array}{l}\text { Natural Logarithm of the Total Assets (in } \\
\text { millions) as a measure of company size }\end{array}$ & $(-)$ \\
\hline $\begin{array}{l}\text { Net Income } \\
\text { (Profitability) }\end{array}$ & Income & $\begin{array}{l}\text { Company's Net Income (in millions) } \\
\text { taken from the PNL Accounts }\end{array}$ & $(-)$ \\
\hline $\begin{array}{l}\text { CATA ratio } \\
\text { (Liquidity) }\end{array}$ & CATA & [Current assets/Total assets] $\times 100 \%$ & $(+)$ \\
\hline $\begin{array}{l}\text { Interest Coverage ratio } \\
\text { (Debt Service) }\end{array}$ & Coverage & $\begin{array}{l}\text { Earnings Before Interest and Taxes } \\
\text { (EBIT) divided by Interest Payments }\end{array}$ & $(-)$ \\
\hline $\begin{array}{l}\text { Macroeconomic } \\
\text { Variables } \\
\text { Short-term Nominal } \\
\text { Interest Rate }\end{array}$ & Sti & 3-month Treasury-Bill rate & $(+)$ \\
\hline Inflation Rate & Inflt & $\begin{array}{l}\text { Measured as the rate of change of the UK } \\
\text { Consumer Price Index }\end{array}$ & $(+)$ \\
\hline Stock Market Volatility & Ftlsh & $\begin{array}{l}\text { Measured as the annualized standard } \\
\text { deviation of the FT All Share Price Index }\end{array}$ & $(+)$ \\
\hline $\begin{array}{l}\text { Current Account } \\
\text { Surplus }\end{array}$ & Current-s & $\begin{array}{l}\text { Natural Logarithm of Exports minus } \\
\text { Imports }\end{array}$ & $(-)$ \\
\hline Growth of GDP & Growthgd & $\begin{array}{l}\text { Measured as the rate of change of the } \\
\text { Gross Domestic Product }\end{array}$ & $(-)$ \\
\hline $\begin{array}{l}\text { Period Dummy for } \\
\text { Recession and } \\
\text { Slowdown }\end{array}$ & Sldown & $\begin{array}{l}\text { Dummy takes the value } 1 \text { for the periods } \\
1988-1992 \text { and } 1999-2001,0 \text { otherwise }\end{array}$ & $(+)$ \\
\hline
\end{tabular}

Table 4 and Table 5 present a summary of descriptive statistics for the financial ratios in our model. Failing companies compared to non-failing companies, are smaller in size, have poor profitability (the average net income being nearly $1 / 3$ of that of the non-failed companies), find it more difficult to pay their debts (the average coverage ratio being seven times smaller than that of the non-failed companies) and lastly have less flexibility to generate cash flows sufficient enough to cover their cash outflows (the average CATA ratio for failed companies is nearly twice as big as of that of the non-failed companies). These results are consistent with previous empirical studies of company bankruptcy (Altman, 1977). The average inflation rate, interest rate, stock market volatility and growth rate of GDP, in the UK, for the period 19802001 , were $5.46 \%, 9.58 \%, 11.55 \%$ and $2.3 \%$, respectively. Please note the very high average equity volatility and the quite high average short-term interest rate for the period. 
Table 4. Summary Statistics for the Failed Companies (16)

\begin{tabular}{lrrrr}
\hline Variables & Mean & $\begin{array}{c}\text { Standard } \\
\text { Deviation }\end{array}$ & Min & Max \\
\hline Size & 10.81 & 1.30 & 8.35 & 12.67 \\
Income & 8466.63 & 15201.88 & -6485.00 & 52545.00 \\
Coverage & 2.30 & 2.70 & -3.08 & 7.03 \\
CATA & 0.45 & 0.32 & 0.003 & 0.94 \\
\hline
\end{tabular}

Note: Numbers for Income are in thousand pounds and for the rest of the independent variables are in percentages

Table 5. Summary Statistics for the Non-Failed Companies (123)

\begin{tabular}{lrrrr}
\hline Variables & Mean & $\begin{array}{c}\text { Standard } \\
\text { Deviation }\end{array}$ & Min & Max \\
\hline Size & 11.47 & 1.65 & 6.50 & 15.87 \\
Income & 27465.46 & 74111.45 & -120000.00 & 1195000.00 \\
Coverage & 15.62 & 96.45 & -61.44 & 1843.00 \\
CATA & 0.28 & 0.29 & 0.0006 & 1.05 \\
\hline
\end{tabular}

Note: Numbers for Income are in thousand pounds and for the rest of the independent variables are in percentages

It would indeed be very useful in such an analysis of credit risk of the UK real estate companies to consider how the different types of property investment (retail, office, residential and industrial) and the geographical region of property investment (South, North, East and West) could potentially affect the probability of default of these companies ${ }^{14}$. Thompson's DataStream and other sources that we checked (Financial Times, London Stock Exchange, Property Week and The Estates Gazette Information Research Centre) do not archive such details about UK property companies (property investment by asset type and geographical region). It is the data limitations, which precludes us from looking deeper into this issue.

\section{A Probit Model for the UK Real Estate Companies: Empirical Results}

We estimate a Probit model using a pooled panel data set for the public UK real estate companies. The estimation results for the Probit specification are presented in Table 6. Specifically, the Table reports the estimated coefficients, the marginal effects, corrected (robust) standard errors for both heteroscedasticity and dependence of observations within firms as well as the t-statistic for each of the explanatory variables.

Company size is found to have a negative effect on the probability of default. This is the so called "too big-to-fail" argument; the larger the company, the lower the probability of failure. It is the case where large mature companies have usually an established reputation as good bank customers and would be viewed by banks as safer risks. Thus, it might be easier for larger companies to find external financing, in more favourable terms compared to smaller companies, during periods that they experience temporary cash flow problems. Although correctly signed, the size coefficient is not statistically significant. We also find that interest coverage has a negative and significantly different from zero effect on the probability of default. This is in line with the economic theory; the higher the EBIT to interest payments the more comfortable the firm will serve its debt and thus less the risk of company default. Another accounting variable, the net income, is found to be negative and significantly different from zero. This is a very standard result in the literature; the higher the net profits for a company the more loose capital is available to finance new investment projects and to reduce debt burden. Our results confirm prior expectations that illiquidity is positively related to financial distress (Ward, 1994 and Lincoln, 1984). Companies with longterm assets have greater flexibility to generate cash-flows sufficient to cover their cash outflows during sudden decreases in cash flow. 
Table 6. Probit Estimation Results

\begin{tabular}{lcccl}
\hline $\begin{array}{l}\text { Explanatory } \\
\text { Variables }\end{array}$ & Coefficients & $\begin{array}{l}\text { Marginal } \\
\text { Effects (dF/dx) }\end{array}$ & $\begin{array}{c}\text { Robust } \\
\text { Standard Error }\end{array}$ & t-statistic \\
\hline Size & -0.06 & -0.00004 & 0.00009 & -0.65 \\
Income & $-5.79 \mathrm{e}-06$ & $-4.11 \mathrm{e}-09$ & $5.56 \mathrm{e}-09$ & $\mathbf{- 2 . 2 6 * *}$ \\
Coverage & -0.03 & -0.00002 & 0.00002 & $\mathbf{- 2 . 9 4 *}$ \\
CATA & 1.18 & 0.00084 & 0.00098 & $\mathbf{2 . 3 0 * *}$ \\
Inflt_1 & -0.14 & -0.00010 & 0.00010 & -0.78 \\
Ftlsh_1 & 3.12 & 0.00222 & 0.00289 & $\mathbf{2 . 6 8 *}$ \\
Sti_1 & 39.30 & 0.02793 & 0.03011 & $\mathbf{2 . 4 1 * *}$ \\
Current-s & -0.00006 & $-4.16 \mathrm{e}-08$ & $4.69 \mathrm{e}-08$ & $\mathbf{- 2 . 9 1 *}$ \\
Growthgd & 12.01 & 0.00854 & 0.01240 & 1.59 \\
Sldown & 1.10 & 0.00474 & 0.00445 & $\mathbf{3 . 1 8 *}$ \\
Constant & -6.51 & - & 1.78410 & $\mathbf{- 3 . 6 5 *}$ \\
Observations & 1331 & & & \\
Log likelihood & $=-54.76453$ & & & \\
Pseudo R & $=0.3679$ & & &
\end{tabular}

Notes: One asterisk denotes significance at the $1 \%$ level and two asterisks denote significance at the $5 \%$ level.

With respect to the macroeconomic variables in our model, we know by intuition that the higher the current account surplus for an economy the less likely it is that the government increase the interest rates in order to finance possible trade imbalances and therefore, the lower the probability of default for domestic companies. The negative sign of the coefficient for the current account surplus verifies prior theoretical assumptions. In contrast, the short-term interest rate lagged one period, is found to be significantly different from zero and positive. When interest rates increase, the interest obligations and payments of the borrowers increase as well. Inability to meet the higher debt obligations is a precipitating factor in a firm's demise. In countries like the UK where most debt contracts are at floating interest rates, the relationship between the short-term interest rate and the probability of default is even stronger. This relationship might hold for any company in any industry but it is particularly strong in the real estate industry because real estate companies are highly leveraged companies ((Ball et al. (1998) and Harvey (2000)), where risks are high ((FDIC (1997), Ball et al (1998) and Lennox (1999)). Moreover, the growth rate of gross domestic product is found to be positive. This is not in line with our prior theoretical assumptions about the relationship between GDP and the probability of default. The demand for commercial space is driven by the level of general economic activity. In this end, we are expecting from economic theory that GDP (as a proxy for employment) should have an inverse relationship with the probability of real estate company default. Its coefficient though is not statistically significant.

Another macroeconomic variable which is found neither to be correctly signed nor statistically significant is the inflation rate lagged one period. There is now a widespread consensus among the economists that inflation is a monetary phenomenon. It is widely accepted that in order to combat high inflation, sooner or later, a government would be forced to reduce money supply. This action is expected to increase interest rates, the debt burden of companies and their probability of default. The standard deviation of the stock market index lagged one period is found to be significantly different from zero and positive. That implies that the stock market volatility has a positive effect at the probability of default, with one period lag. If uncertainty prevails in the stock market, for example due to uncertainty about the economic growth prospects of an economy etc. it will naturally increase the volatility of the stock market. In this case, companies might find it difficult to raise new money from the issuance of new shares and it is likely that they will have to rely on the more expensive debt-financing alternative. Lastly, the period Dummy for 
economic recession (1988-1992) and slowdown (1999-2001) in the UK is found to be significantly different from zero and positive. Periods of economic slowdown or recession are expected to be associated with higher company defaults. As we show in Table 2 above, there is a clustering of defaults of real estate companies around the periods that recession hit the UK economy.

Pseudo- $\mathrm{R}^{2}$ stands in one-to-one relation with the Chi-squared statistic for testing the hypothesis that the coefficients on all variables (overall significance) apart from the constant are jointly zero (Dhrymes, 1986). Pseudo- $\mathrm{R}^{2}$ is admittedly quite low but Wooldridge (2000) argues that in binary response models "goodness-of-fit is not as important as statistical significance and economical significance of the explanatory variables". Moreover, it is very common in empirical work in the bankruptcy literature to get very low magnitude for the Pseudo- $\mathrm{R}^{2}$ ((Lennox, (1999) gets 0.2169, Smith and Lawrence (1995) get 0.15, Lawrence, Smith and Rhoades (1992) get 0.29)). Lastly, pseudo $\mathrm{R}^{2}$ does not have the usual interpretation of explained variation/total variation because the binary response Probit model is a non-linear regression model. In most applications of binary response models one of the goals is to explain the effects of changes in any of the explanatory variables $\mathrm{X}_{\mathrm{i}}$ on the response probability $\operatorname{Pr}\left(\mathrm{Y}_{\mathrm{it}}=1\right)$. It is important to know that the magnitudes of the coefficient estimates of the Probit model, like in any other non-linear regression model, are not especially useful and this is because they do not represent "marginal effects". Marginal effects give the partial effect of a roughly continuous variable on the response probability. This is obtained from the partial derivative $\vartheta \operatorname{Pr}\left(\mathrm{Y}_{\mathrm{it}}=1\right) / \vartheta \mathrm{X}_{\mathrm{it}}$. Marginal effects depend upon the point at which the probabilities are evaluated, and this point is conventionally chosen as the vector of sample means. The magnitude of the marginal effects in our model is very low. It is very common though for empirical work that includes financial ratios (measured in percentages) as explanatory variables to get very low magnitude for the regression coefficients. Other authors in the bankruptcy literature also get very low marginal effects ((Foreman, (2003), Lennox, (1999), and Smith and Lawrence (1995)).

\section{Conclusion}

Although the Probit and Logit models have dominated the credit risk literature, this is the first attempt ever to apply quantitative credit risk models to a UK real estate data set. Our data set, compiled by means of using information from Thompson's DataStream and the financial press, is unique. It includes company accounts for (nearly) the whole population of the de-listed (16 defaulted, 54 taken-over and 19 management buy-outs) and the listed (50 non-failed) commercial real estate companies, over the period 1980 to 2001. We pool the data of the total number of the UK real estate companies and run a Probit regression for the period 1980-2001. In our model we include a number of financial ratios because the risk position of a company varies with the state of the balance sheet and profit and loss accounts.

We find that profitability, the debt service and company's liquidity are statistically significant determinants of the probability of default of real estate companies in the UK. The distinctive feature of this study is that it tests the extent to which macroeconomic/financial circumstances also contribute to real estate company failure. We include a number of key macroeconomic and financial variables because default risk for all borrowers depends on the state of the financial and economic cycle. As we show in Table 2 there is a clustering of defaults of real estate companies around the periods that recession/slowdown (1988-1992 and 1999-2001) hit the UK economy. Business cycle fluctuations are the main cause of most defaults which occur during or immediately after recessions. This pattern is -evidentlya sign of post cyclicality. This is especially the case in industries like construction and commercial real estate, which are prone to cyclical activity. We find that variables such as interest rates, current account surplus, stock market volatility, and the period Dummy for recession (1988-1992) and slowdown (19992001) significantly affect, with one-year time lag, the probability of default of real estate companies in the UK. Should and can anything be done in order to prevent a repetition of the property market collapse and banking crises of the early 90's in the UK and their negative repercussion effects to the whole economy? Our econometric model for the UK real estate companies reveals interesting insights about the determinants of company failure. This information might be useful for the industry professionals, policy makers and the real estate lenders. They need to seriously pay attention to economic (changes in the interest rates and the current account) and financial environment (uncertainty in the financial market) changes because these changes might lead to an unforeseen deterioration in the credit standing of bank's counter-parties for example real estate companies. This might induce financial fragility which can, in turn, cause a nonperforming loans crisis (Ernst and Young, 2004), bank failures and consequently a general economic crisis. 
We believe that the results presented in this paper contribute to the existing literature on default risk. They suggest an early warning system that takes into account the state of the macro-economy as a contributory factor explaining real estate corporate failure is an attainable goal. Ultimately, the real issue is how well the models work and to what extent their use contributes to improved financial performance of a company. A conceptual model for the UK real estate companies (like the contingent claims approach employed by Patel and Vlamis, 2006) that performs well in terms of classification accuracy, has an advantage over a statistical model (like the Probit binary response model that we use here), which does not, and vice versa. To the best of our knowledge there are no published comparisons of these different research methodologies for the UK real estate companies. A comparative analysis of credit risk models for the UK real estate industry is next in our research agenda.

\section{Notes}

1. Dr Prodromos Vlamis is with the Department of Land Economy, University of Cambridge, UK. This paper has been greatly benefited from the constructive suggestions of Piet Eichholtz. We wish also to thank Konstantinos Tatsiramos and Dimitris Georgarakos for valuable suggestions, which greatly improved the paper. I would also like to thank conference participants at the $5^{\text {th }}$ Global Conference on Business and Economics, Cambridge, July 6-8, 2006, UK and the $10^{\text {th }}$ International Conference of the Economic Society of Thessaloniki, Thessaloniki, November 9-11, 2006, Greece, for useful comments. Special thanks go to the discussant of the paper, Professor Wei Wang of Feng Chia University, Taiwan and an anonymous referee for her valuable suggestions and comments. This work has been undertaken at Harvard University during the academic years 2004 - 2006 while the author was a visiting research fellow. Financial support from the Harold Pollman Fellowship at Harvard and the Hellenic Harvard Foundation is gratefully acknowledged. Corresponding address: University of Cambridge, Department of Land Economy, 19 Silver street, Cambridge, CB3 9EP, U.K. E-mail: pv214@cam.ac.uk

2. Interest rates increased from $8.3 \%$ in 1988 to $12.6 \%$ in 1989 , to $14.5 \%$ in 1990 , to $13.4 \%$ in 1991 and to $15 \%$ immediately after the speculative attack to the British pound on the $16^{\text {th }}$ September 1992 (the so called "Black Wednesday").

3. Most of the household and company debt is in floating rate in the UK. Particularly, the vast majority of loans to firms (around $90 \%$ of gross loans) are at variable interest rates. Also, a very high proportion of mortgage loans to households (around $90 \%$ of the stock of mortgages) have variable interest rates ((Rowlatt (1993), Artis and Lewis (1993), Lewis (1994) and Miles (1994)).

4. Please see Browne and Case (1992), FDIC (1997), Caouette et al (1998), Hilbers et al (2001), Collyns and Senhadji (2002), Quigley (2001) and Siebert (2002).

5. A conceptual approach tells us which variables should be important and how they should be combined mathematically.

6. An econometric approach identifies important factors based on experience.

7. Although straightforward, the LPM method faces serious econometrics problems and is rather out of date. That's why we do not analyse it here. For the problems (non-normality of the disturbances, heteroscedastic variances of the variances, questionable value of $\mathrm{R}^{2}$ as a measure of goodness of fit etc.) in estimation of LPM see Gujarati (2003).

8. Please see Beaver (1966), Altman (1968), Meyer and Pifer (1970), Sinkey (1975), Martin (1977), Korobow, Stuhn and Martin (1977), Santomero and Vinso (1977), Sinkey (1978), Pettway and Sinkey (1980), Amemiya (1981), Scott (1981), Taffler (1984), Korobow and Stuhr (1985),West (1985), Peel et al (1986), Burton and Cliff (1987), Pantalon and Platt (1987), Goudie A. (1987), Whalen and Thomson (1988), Peel and Peel (1988), Gajewski (1989), Demirguc-Kunt (1989), Platt and Plat (1991), Pouran (1991), Thomson (1991), Lawrence, Smith and Rhoades (1992), Smith and Lawrence (1995), Kumar and Arora (1995), Hooks (1996), Morris R. (1997), Heffernan (1995 and 1996), Lennox (1999), Kolari et al (2002) and Foreman (2003).

9. Information collected form Financial Times, the Estates Gazette Information Research Center and practitioners' journals i.e. Property Week.

10. The purchase of a business by part or all of its existing management with the help of a group of financial backers, such as, specialist divisions of commercial banks or investment banks and venture capital funds.

11. This involves state (choice) based samples with equal numbers of failed and non-failed firms, each group typically also "matched" to size and industrial classification. The matched pairing procedure 
produces an experimental sample of companies, which is not representative of the population of the non-failed companies. The matched pairing approach assumes that there is an equal 50:50 percent probability of any firm selected from the wider population of companies being a potential failure. In that respect a sampling bias is introduced. For more on the matched pairing procedure and its problems see Palepu (1986) and Morris (1997).

12. Mergers \& acquisitions add value only if they generate additional economic rents; providing a further competitive edge that is not easily reproduced. Motives include the following: synergies, revenue enhancement, cost reductions, ability to swap unused tax shields and use of surplus funds and economies of scope (combining complementary resources).

13. Book value of common equity, total capital employed, current assets, current liabilities, capitalization rate (proxy for capital adequacy), working capital ratio (proxy for capital liquidity), total assets (proxy for company size), total liabilities, market value of equity, equity/liabilities, total liabilities/ total assets (proxy for capital liquidity), return on assets, coverage (proxy for debt service), retentions (proxy for profitability), property revenue, profits, current liabilities/ total liabilities, trading profit margin, return on capital, current assets/total assets, income gearing and borrowing ratio.

14. For example, we expect that real estate companies investing in the office market (purchase of existing assets) or developing office space (create new fixed assets) face lower risks (thus, lower probability of default) lower than companies investing in industrial factories and warehouses. As a result, offices' yields tend to be less than those of industrial and residential properties. This is the case because prime offices can often be let to a single tenant providing an excellent covenant. Also, industrial premises tend to be less popular as investments due to the high risks involved. For example "many factories are built for a special purpose and if they have to be relet difficulty may be experienced in finding a similar tenant, or, alternatively, expense is incurred in adaptation" (Harvey, 2000).

\section{References}

Altman, E., (1968), "Financial Ratios Discriminant Analysis and the Prediction of Corporate Bankruptcy", September, 23, Journal of Finance, 589-609.

Altman, E., Haldeman R. and Narayanan P. (1977), "Zeta Analysis: A New Model to Identify Bankruptcy Risk of Corporations", Journal of Banking and Finance, 1, 29-54.

Altman, E. and Saunders, A., (1998), "Credit Risk Measurement: Developments Over the Last 20 Years", Journal of Banking and Finance, 21, 1721-1742.

Amemiya, T., (1981), "Qualitative Response Models: A Survey", Journal of Economic Literature, 19, 1483-1536.

Anderson, R. and Sundaresan, S., (2000), "A Comparative Study of Structural Models of Corporate Bond Yields: An Exploratory Investigation”, Journal of Banking and Finance, 24, 255-269.

Artis, M. and Lewis, M., (1993), "Apres de Deluge: Monetary and Exchange-Rate Policy in Britain and Europe", Oxford Review of Economic Policy, 9(3), 36-61.

Ball, M., Lizieri, C. and MacGregor, B., (1998), The Economics of Commercial Property Markets, Routledge.

Beaver, W., (1966), "Financial Ratios as Predictors of Failure”, Journal of Accounting Research, 4 (supplement), 71-111.

Browne, L. and Case, K., (1992), "How the Commercial Real Estate Boom Undid the Banks" in Browne, L and Rosengren, E., (eds.) Real Estate and the Credit Crunch, Conference Proceedings, Federal Reserve Bank of Boston, 57-98.

Burton, A. and Cliff, J., (1987), "Predicting Bank Failures: the Role of Structure in Affecting Recent Failure Experience in the USA", Applied Economics, 19, 1291-1302.

Caouete, J., Altman, E. and Narayanan, P., (1998), Managing Credit Risk, the Next Great Financial Challenge, J.Wiley and Sons.

Collyns, C. and Senhadji, A., (2002), "Lending Booms, Real Estate Bubbles, and the Asian Crisis", working paper 02/20, International Monetary Fund.

Davis, E., (1995), Debt Financial Fragility and Systemic Risk, Oxford University Press

Demirguc-Kunt, A., (1989), "Deposit-Institution Failures: A Review of Empirical Literature", FRB of Cleveland, Economic Review, $4^{\text {th }}$ Quarter, 2-18.

Dhrymes, P., (1986), "Limited Dependent Variables", in Griliches, Z. and Intriligator, M., (eds). Handbook of Econometrics Volume III. New York: North-Holland, 1568-1631.

Ernst \& Young, (2004), Global Non-performing Loan Report 2004. 
Eichholtz, P., Kok, N. and Otten, R., (2004), "Executive Compensation in UK Property Companies", mimeo, Maastricht University.

Estates Gazette Information Research Center.

Federal Deposit Insurance Corporation (FDIC), (1997), "Commercial Real Estate and the Banking Crisis of the 1980s and early 1990s", chapter 3 in An Examination of the Banking Crisis of the 1980s and Early 1990s, volume 1.

Financial Times, daily British financial newspaper, various issues.

Foreman, R., (2003), "A Logistic Analysis of bankruptcy within the US Local Telecommunications Industry", Journal of Economics and Business, 55, 135-166.

Gajewski, R., (1989), "Assessing the Risk of Bank Failure", in Bank Structure and Competition, Conference Proceedings, FRB of Chicago, 432-446.

Goudie, A., (1987), "Forecasting Corporate Failure: The Use of Discriminant Analysis within a Disaggregated Model of the Corporate Sector", Journal of Royal Statistical Society, 150(1), pp. 69-81.

Gujarati, D., (2003), Basic Econometrics, $4^{\text {th }}$ ed., McGraw-Hill Higher Education.

Harvey, J., (2000), Urban Land Economics, $5^{\text {th }}$ edition, MacMillan Press.

Heffernan, S., (1995), “An Econometric Model of Bank Failure”, Economic and Financial Modelling, Summer, 49-83.

Heffernan, S., (1996), Modern Banking in Theory and Practice, John Wiley \& Sons Inc.

Hilbers, P., Lei, Q. and Zacho, L., (2001), "Real Estate Market Developments and Financial Sector Soundness", working paper 01/129, International Monetary Fund.

Hooks, L., (1996), "Bank Asset Risk: Evidence from Early Warning Models", Contemporary Economic Policy, 13(4), 36-50.

Journal of Banking and Finance, (1984), Special Issue, Company and Country Risk Models, 8(2), 151-387.

Kane, G., Richardson, F. and Graybeal, P., (1996), "Recession-Induced Stress and the Prediction of Corporate Failure", Contemporary Accounting Research, 13(2), 631-650.

Kolari, J., Glennon, D., Shin, H., and Caputo, M., (2002), "Predicting large US Commercial Bank Failures", Journal of Economics and Business, 54, 361-387.

Korobow, L., Stuhn, D. and Martin, D., (1977), "A Nationwide Test of Early Warning Research in Banking", FRB of New York, Quarterly Review, Autumn, 37-52.

Korobow L. and D. Stuhr (1985), "Performance Measurement of Early Warning Models", Journal of Banking and Finance, 9, 267-273.

Kumar, S. and Arora, S., (1995), "A Model for Risk Classification of Banks", Managerial and Decision Economics, 16, 155-165.

Lawrence, E., Smith, L. and Rhoades, M., (1992), "An Analysis of Default Risk in Mobile Home Credit", Journal of Banking and Finance, 16, 299-312.

Lennox, C., (1999), "Identifying Failing Companies: A Re-evaluation of the Logit, Probit and DA Approaches", Journal of Economics and Business, 51, 347-364.

Lewis, K., (1994), "Banking on Real Estate", in Fair, D. and Raymond, R., (eds.) The Competitiveness of Financial Institutions and Centres in Europe, Kluwer Academic Publishers, 47-71.

Lincoln, M., (1984), "An Empirical Study of the Usefulness of Accounting Ratios to Describe Levels of Insolvency Risk", Journal of Banking and Finance, 1, 321-340.

Logan, A., (2000), “The Early 1990s Small Banks Crisis: Leading Indicators", Financial Stability Review, December, Bank of England.

Martin, D., (1977), "Early Warning of Bank Failure. A Logit Regression Approach", Journal of Banking and Finance, 1, 249-276.

Meyer, P. and Pifer, H., (1970), "Prediction of Bank Failure", Journal of Finance, September, 25, 853-868.

Miles, D., (1994), "Fixed and Floating-Rate Finance in the United Kingdom and Abroad" Bank of England Quarterly Bulletin, February, 34-45.

Morris, R., (1997), Early Warning Indicators of Corporate Failure: a critical review of previous research and further empirical evidence, Ashgate.

Patel, K. and Vlamis, P., (2006), "An Empirical Estimation of Default Risk of the UK Real Estate Companies", Journal of Real Estate Finance and Economics, 32(1), 21-40

Palepu, K., (1986), "Predicting Takeover Targets, A Methodological and Empirical Analysis", Journal of Accounting and Economics, 8, 3-35.

Pantalon, C. and Platt, M., (1987), "Predicting Commercial Bank Failures since Deregulation", FRB of 
Boston, New England Economic Review, July/August, 37- 47.

Peel, M. and Peel, D., (1988), “A Multilogit Approach to Predicting Corporate Failure- Some Evidence for the UK Corporate Sector”, Omega, 16(4), 309-318.

Peel, M., Peel, D. and Pope, P., (1986), "Predicting Corporate Failure- Some Results for the UK Corporate Sector", Omega, 14(1), 5-12.

Pettway, R. and Sinkey, J., (1980), "Establishing on-site Bank Examination Priorities: An Early-Warning System using Accounting and Market Information", Journal of Finance, 35(1), 137-150.

Plat, H. and Platt, M., (1991), "A note on the Use of Industry-Relative Ratios in Bankruptcy Prediction", Journal of Banking and Finance, 15, 1183-1194.

Pouran, E., (1991), "Identification of Problem Banks and Binary Choice Models", Journal of Banking and Finance, 15, 53-71.

Property Week, 01/08/2003 and other issues, weekly UK Real Estate practitioners magazine.

Quigley, J., (2001), "Real Estate and the Asian Crisis", Journal of Housing Economics, 10, 129-161.

Rowlatt, A., (1993), "UK Sensitivity to Short Term Interest Rates”, Treasury Bulletin, 4(2), 52-65, HMSO, London

Santomero, A. and Vinso, J., (1977), "Estimating the Probability of Failure for Commercial Banks and the Banking System", Journal of Banking and Finance, 1, 185-205.

Scott, J., (1981), "The Probability of Bankruptcy: A Comparison of Empirical Predictions and Theoretical Models", Journal of Banking and Finance,5(3), 317-344.

Siebert, H., (2002), The World Economy, $2^{\text {nd }}$ ed., Routledge.

Sinkey, J., (1975), "A Multivariate Statistical Analysis of the Characteristics of Problem Banks", Journal of Finance, 30(1), 21-36.

Sinkey, J., (1978), "Identifying Problem Banks: How Do the Banking Authorities Measure a Bank's Risk Exposure?", Journal of Money, Credit and Banking, 10(2), 184-193.

Smith, I. and Lawrence, E., (1995), "Forecasting Losses on Liquidating Long-Term Loan Portfolio", Journal of Banking and Finance, 19, 959-985.

Taffler, R., (1984), "Empirical Methods for Monitoring of UK Corporations”, Journal of Banking and Finance, June, 8(2), 199-227.

Thomson, J., (1991), "Predicting Bank Failures", FRB of Cleveland, Economic Review, 27(1), 9-20.

Ward, T., (1994), "Cash Flow Information and the Prediction of Financially Distressed Mining, Oil and Gas Firms: A Comparative Study", Journal of Applied Business Research, 78-86.

West, R., (1985), "A Factor-Analytic Approach to Bank Condition", Journal of Banking and Finance, 9 , 253-266.

Whalen, G. and Thomson, J., (1988), "Using Financial Data to Identify Changes in Bank Condition", FRB of Cleveland, Economic Review, 24(2), 17-26.

Wooldridge, J., (2000), Introductory Econometrics: a Modern Approach, South-Western College Publishing. 
Appendix I

Table 1. Description of the Non-Failed Companies (50)

\begin{tabular}{|c|c|c|c|}
\hline Company Name & $\begin{array}{l}\text { Market Cap/tion } \\
\quad(£ \mathrm{~m})\end{array}$ & $\begin{array}{l}\text { London Share } \\
\text { Service }\end{array}$ & $\begin{array}{l}\text { Period of } \\
\text { Analysis }\end{array}$ \\
\hline Benchmark Group & 233.0 & Real Estate & $1989-2000$ \\
\hline Ashtenne Holdings & 116.0 & Real Estate & 1997-1999 \\
\hline British Land Company & $2,000.0$ & Real Estate & $1980-2000$ \\
\hline Capital \& Regional Properties & 216.0 & Real Estate & $1986-2000$ \\
\hline Brixton Estate & 522.0 & Real Estate & $1980-2000$ \\
\hline Cardiff Property & 12.0 & Real Estate & $1983-2000$ \\
\hline CLS Holdings & 149.0 & Real Estate & 1994-1999 \\
\hline Daejan Holdings & 142.0 & Real Estate & $1980-2000$ \\
\hline DTZ Holdings & 80.9 & Real Estate & 1988-1999 \\
\hline Derwent Valley Holdings & 281.0 & Real Estate & $1984-2000$ \\
\hline Hampton Trust & 21.0 & Real Estate & $1986-2000$ \\
\hline Land Securities & $4,000.0$ & Real Estate & $1980-2000$ \\
\hline Helical Bar & 168.0 & Real Estate & $1987-2000$ \\
\hline Laing John & 337.0 & Support Services & 1995-1999 \\
\hline London \& Associated Properties & 17.0 & Real Estate & $1991-2000$ \\
\hline Mowlem John & 302.0 & Construction & $1981-2000$ \\
\hline Newport Holdings & 13.0 & Real Estate & 1994-2000 \\
\hline Panther Securities & 25.0 & Real Estate & 1994-2000 \\
\hline Rugby Estates & 22.0 & Real Estate & 1994-2001 \\
\hline Slough Estates & $1,000.0$ & Real Estate & $1981-2000$ \\
\hline Liberty Group & $1,400.0$ & Real Estate & $1996-2000$ \\
\hline London Merchant Securities & 442.0 & Real Estate & $1991-2000$ \\
\hline McKay Securities & 56.0 & Real Estate & $1981-2000$ \\
\hline Mountview Estates & 112.0 & Real Estate & $1983-2000$ \\
\hline Pillar Property & 422.0 & Real Estate & $1995-2000$ \\
\hline Quintain Estates \& Development & 172.0 & Real Estate & $1997-2000$ \\
\hline Stewart \& Wight & 4.0 & Real Estate & $1991-2000$ \\
\hline Workspace Group & 128.0 & Real Estate & 1994-2000 \\
\hline Savills & 250.0 & Real Estate & $1989-2000$ \\
\hline Shaftesbury & 294.0 & Real Estate & $1988-2000$ \\
\hline Warner Estate Holdings & 121.0 & Real Estate & 1980-1999 \\
\hline Mucklow (A \& J) Group & 158.0 & Real Estate & $1981-2000$ \\
\hline J Smart \& Co & 26.0 & Real Estate & $1992-2000$ \\
\hline St Modwen Properties & 119.0 & Real Estate & $1986-2000$ \\
\hline Town Centre Securities & 92.0 & Real Estate & $1981-2000$ \\
\hline Primary Health Properties & 18.0 & Real Estate & $1996-2000$ \\
\hline Marylebone Warwick Balfour & 115.0 & Real Estate & $1996-2000$ \\
\hline \multicolumn{4}{|l|}{ Group } \\
\hline Smith (James) Estates & 30.0 & Real Estate & $1990-2001$ \\
\hline London Town & 6.0 & AIM & $1997-2000$ \\
\hline Probus Estates & 11.0 & AIM & $1997-2000$ \\
\hline Solitaire Group & 12.0 & AIM & $1997-2000$ \\
\hline Peel Holdings & 503.0 & AIM & $1983-2000$ \\
\hline Grosvenor Land Holdings & 4.0 & AIM & $1997-2000$ \\
\hline Clan Homes & 1.1 & AIM & $1997-2000$ \\
\hline London Securities & 202.7 & AIM & 1983-1999 \\
\hline NHP & 86.0 & Real Estate & $1996-2000$ \\
\hline Cathay International Holdings & 13.0 & Leisure and Hotels & $1992-2000$ \\
\hline Safeland & 9.0 & Real Estate & $1989-2000$ \\
\hline Caledonian Trust & 6.0 & AIM & $1996-2000$ \\
\hline
\end{tabular}

Note: Market capitalization data is from Financial Times as it was standing on the $3^{\text {rd }}$ of April 2000 
Table 2. Description of the Failed Companies (16)

\begin{tabular}{lcl}
\hline Company Name & Date of De-listing & Period of Analysis \\
\hline Abaco Investments & $02 / 02 / 1988$ & $1984-1986$ \\
Speyhawk & $29 / 05 / 1993$ & $1982-1991$ \\
Regent Crest & $09 / 10 / 1990$ & $1985-1989$ \\
Bilton Percy ACC & $05 / 05 / 1992$ & $1987-1991$ \\
Bolton Group International & End of 2002 & $1990-2000$ \\
Criterion Properties & End of 2002 & $1990-2000$ \\
Creston & End of 2000 & $1991-2000$ \\
Stockbourne & End of 2002 & $1996-2000$ \\
Palmerston Investment Trust & $19 / 07 / 1988$ & $1982-1988$ \\
Citabel Holdings & $22 / 01 / 2001$ & $1997-1999$ \\
County Properties & $13 / 07 / 1988$ & $1985-1987$ \\
Hanover Druce & $14 / 12 / 1991$ & $1988-1990$ \\
Ryan International & $11 / 04 / 1989$ & $1980-1987$ \\
Law Land & $16 / 04 / 1985$ & $1980-1984$ \\
Rush \& Tompkins & $12 / 05 / 1990$ & $1984-1989$ \\
Prestbury Group & $04 / 10 / 2000$ & $1997-1999$ \\
\hline
\end{tabular}

Table 3. Description of the Companies De-Listed due to Takeover or Merger (54)

\begin{tabular}{llrl}
\hline Company Name & Date of & $\mathbf{E}(\mathbf{m})$ & Period of Analysis \\
& T/O-Merger & & \\
\hline London Shop & T/O- 3/01/1989 & 304.5 & $1980-1988$ \\
Marler Estates & T/O-24/06/1989 & 82.4 & $1982-1989$ \\
IN Shops & T/O-26/02/1994 & 58.0 & $1991-1993$ \\
Brightstone Properties & T/O-20/06/1996 & 9.0 & $1994-1995$ \\
Local London Group & T/O-23/03/1989 & 110.9 & $1986-1988$ \\
Chesterfield Properties & T/O-28/05/1999 & 140.0 & $1980-1998$ \\
Trafford Park Estates & T/O-18/07/1998 & 146.0 & $1980-1997$ \\
Park Estates (Liverpool) & T/O-22/05/1999 & 7.3 & $1995-1988$ \\
Lands Improvement & T/O-26/11/1999 & 42.4 & $1996-1998$ \\
Allied London Properties & T/O-25/02/2000 & 138.0 & $1980-1999$ \\
BPT & T/O-15/05/2001 & 477.0 & $1980-2000$ \\
Cleveland Trust & T/O-09/04/1999 & 33.0 & $1994-1998$ \\
Bourne End Properties & T/O-15/01/2001 & 42.0 & $1989-1999$ \\
Asda Property & T/O-14/09/2001 & 232.0 & $1985-2000$ \\
Ashquay Group & Reverse T/O- & 13.7 & $1987-2000$ \\
& 20/07/2001 & & \\
Dencora & T/O-11/08/2000 & 74.6 & $1982-1999$ \\
Haslemere Estates & T/O-29/03/1986 & 245.0 & $1980-1984$ \\
Compco Holdings & T/O-20/06/2003 & 147.0 & $1982-2000$ \\
UK Land & T/O-11/10/2002 & 29.0 & $1996-2000$ \\
Jermyn Investment Pro/ties & T/O-11/05/2001 & 100.8 & $1983-1999$ \\
Capital Shopping Centres & T/O-10/11/2000 & - & $1994-1999$ \\
Capital \& Counties & T/O-30/05/1992 & 123.0 & $1980-1991$ \\
Olives Property & T/O- April 1998 & 28.6 & $1990-1997$ \\
Lambert Smith Hampton & T/O-25/06/1999 & 50.0 & $1989-1999$ \\
Birkby & Merger-30/07/1999 & 160.0 & $1992-1999$ \\
Hemingway Properties & T/O-27/08/1999 & 119.0 & $1987-1998$ \\
Beazer Group & T/O- March 2001 & 560.0 & $1994-2000$ \\
Bryant Group & T/O- March 2001 & 535.0 & $1980-2000$ \\
Speciality Shops & T/O-18/10/1997 & 36.0 & $1994-1996$ \\
Morrison Construction & T/O-August 2000 & 262.5 & $1996-2000$ \\
\hline
\end{tabular}




\begin{tabular}{llrl}
\hline Parkdale Holdings & T/O-24/06/1989 & 56.5 & $1985-1988$ \\
London and Metropolitan & T/O-March 1998 & 6.4 & $1986-1997$ \\
New England Properties & T/O-11/01/1992 & 17.9 & $1983-1990$ \\
Apex Properties & T/O-04/04/1987 & 14.5 & $1982-1986$ \\
BHH Group & T/O-09/05/1992 & 21.4 & $1982-1991$ \\
Bexbuild Development & T/O-24/04/1993 & - & $1990-1992$ \\
Chase Property Holdings & T/O-23/12/1987 & 198.4 & $1983-1987$ \\
Centrovincial Estates & T/O-28/03/1987 & 90.0 & $1982-1986$ \\
IMRY Property & Merger -17/01/1987 & 53.3 & $1980-1984$ \\
Lynton Holdings & Merger -14/01/1987 & 128.0 & $1980-1986$ \\
Lynton Property \& & T/O-21/05/1988 & 220.0 & $1980-1988$ \\
Reversionary & & & \\
Mayfair \& City & Merger -27/06/1987 & 28.2 & $1985-1987$ \\
Property Holding \& & T/O-13/12/1986 & - & $1980-1986$ \\
Investment Trust & & & \\
Stock Conversion & T/O-30/05/1986 & 402.0 & $1980-1985$ \\
Webb Joseph & T/O-05/11/1988 & 17.9 & $1983-1988$ \\
Land Investors & T/O-10/05/1986 & 74.0 & $1980-1986$ \\
Trevian Holdings & T/O-11/02/1992 & 34.9 & $1988-1991$ \\
United Real Property & T/O-06/09/1986 & - & $1980-1986$ \\
Standard Securities & T/O-28/03/1987 & 40.0 & $1982-1986$ \\
New Cavendish Estates & T/O-21/11/1992 & 6.5 & $1988-1992$ \\
Samuel Property & T/O-03/06/1986 & 86.0 & $1980-1985$ \\
Peachey Property & T/O-30/09/1988 & 265.0 & $1980-1988$ \\
Priest Marians & Merger-20/10/1990 & 13.2 & $1986-1989$ \\
\hline
\end{tabular}

Note: In a very few cases, we could not be able to identify the value (in pounds) of the takeover

Table 4. Description of the Companies De-Listed due to Management Buyout or Went Private (19)

\begin{tabular}{llrl}
\hline Company Name & $\begin{array}{l}\text { Date of } \\
\text { MBO-Private }\end{array}$ & $\mathbf{E}(\mathbf{m})$ & Period of Analysis \\
\hline Burford Holdings & MBO-15/12/2000 & 498.0 & $1988-1999$ \\
Barlows & MBO-25/05/2001 & 37.0 & $1988-1999$ \\
Delancey & MBO-12/04/2001 & 264.0 & $1996-2000$ \\
Saville Gordon Estates & MBO-31/05/2002 & 500.0 & $1991-2000$ \\
Chelsfield & MBO-26/01/2004 & 895.5 & $1993-2000$ \\
City Site Estates & MBO-19/12/1998 & 4.4 & $1982-1997$ \\
Pemberstone & MBO-09/04/1999 & 32.3 & $1995-1997$ \\
Raglan Property & MBO-18/08/2000 & 51.4 & $1982-2000$ \\
Greycoat & MBO-28/05/1999 & 330.0 & $1980-1999$ \\
Regalian Properties & MBO-11/05/2001 & 84.3 & $1981-2000$ \\
Merivale Moore & MBO-08/10/2003 & 34.0 & $1986-2000$ \\
Orb Estates & MBO-18/08/2000 & 24.0 & $1985-1999$ \\
Caledonian Trust & MBO-18/06/1987 & - & $1983-1987$ \\
MEPC & Private-10/08/2000 & $1,900.0$ & $1981-2000$ \\
Warnford Investments & Private- May 2001 & - & $1980-1999$ \\
UK Estates & Private-09/10/1998 & - & $1982-1998$ \\
Aqis Securities & Private-02/10/1984 & - & $1980-1983$ \\
Argent Group & Private-24/09/1997 & 18.0 & $1994-1996$ \\
Property Trust & Private-18/08/2001 & - & $1987-2000$ \\
\hline
\end{tabular}

Note: In a very few cases, we could not be able to identify the value (in million pounds) of the MBO. 